\title{
PERFORMANCE OF CONCRETE BY USING HYPO SLUDGE AS A MINERAL ADMIXTURE
}

\author{
V. Mallikarjuna Reddy ${ }^{1}$, B. Sharada ${ }^{2}$, \\ ${ }^{1}$ Head of the Department, Department of Civil Engineering, Gokaraju Rangaraju Institute of Engineering and Technology, \\ Hyderabad, India. \\ ${ }^{2}$ Post graduation student, Department of Civil Engineering, Gokaraju Rangaraju Institute of Engineering and Technology, \\ Hyderabad, India.
}

\begin{abstract}
Increase in the paper waste from paper industries become most serious disposal problem by occupying large space and environmental pollution which is raising every day. To reduce the paper waste and environmental pollution, it is proposed to use the paper waste as Hypo sludge in concrete mix which contains cementitious properties like silica and magnesium. The main ingredient of concrete is cement. During the manufacturing of cement, large amount of carbon dioxide is released into the environment which causes global warming. To control environmental pollution from cement industries, Hypo sludge is used as a partial replacement of cement so that it can reduce cement content and support as an eco-friendly building material. In this research cement is replaced with fly ash and Hypo sludge. By adding 0 percent, 3 percent, 6 percent, 9 percent 12percent and 15percent of hypo sludge, compressive and split tensile strength of concrete and also performance of Hypo sludge concrete are studied. From the experiment, compressive strength and split tensile strength of Hypo sludge concrete increases up to optimum dosage.
\end{abstract}

\section{Introduction}

Energy plays a vital role in developing countries production. The value of using industrial waste is very important due to the low availability of nonrenewable energy resources, along with the demands of large quantities of energy for building materials like cement. Portland cement plays an important role in construction. Volume of carbon dioxide is released into the atmosphere to create one ton of Portland cement is of same quantity, which results in greenhouse effect. Therefore, in order to save the world from global warming, various cement binders with cement products such as hypo sludge, fly ash, silica fume, GGBS, metakoline etc. should be substituted in cement. To minimise the problems of pollution and disposal from these industrial waste, it is utmost important to create useful building materials from the waste. Use of Hypo sludge is considered as one of the sustainable techniques in this respect. The H.Sludge includes low calcium, high calcium chloride and minimal quantity of silica and behaves like mortar due to the properties of calcium and magnesium. This reduces the concrete life because of the presence of toxic gasses found in the environment.

This paper discusses in a concise way the technological and environmental benefits of using additional cemented components, as well as the drawbacks, requirements and specifications

\section{Necessity of Research}

In present era paper usage is very high.

According to recent data, in India the paper consumption float between 9 and 13 kilograms per capita.

During manufacturing of paper there is lots of solid waste is produced. Recycling can be done for restricted number of times to prepare good quality paper. So that the remaining waste material is removed for the manufacturing process which is paper waste (hypo sludge). This hypo sludge create a disposal problem because it occupies larger space and environmental pollution. To reduce the paper waste and environmental pollution, it is proposed to use the hypo sludge in concrete.

\section{Literature review}

Santosh Ahirwar et al (2018) in this research work hypo sludge is partially replaced by OPC cement with different percentages of dry weight of cement. The experiment was conducted on M40 
grade concrete as per relevant IS code of practice based on that test results are obtained. The target strength attained mix of $10 \%$ of hypo sludge in concrete. After that increasing $\%$ strength will decreases.

Y. Suneel Kumaret al (2017) in this research work M30 grade mix is prepared as per IS code of practice.in this experimental work hypo sludge, glass fibers and jute fibers are partially replaced by cement. Compressive, flexural and split tensile strength of concrete will decreased with increasing \% of replacement, and workability decreases with addition of fibers.

Kiran Kumar Poloju et al (2016) in this experimental work M20 grade concrete is used. In this research compressive, flexural, split tensile strength of concrete and Sorptivity, acid effects test performed on concrete as well as cost analysis done.

R .Balamurugan along with R. Karthickraja (2014) create low cost concrete by combining various cement ratios with hypo sludge. Research is concerned with experimental investigation of concrete strength and optimum percentage of partial replacementby replacing cement with 5\%, $10 \%, 15 \%, 20 \%$ of hypo sludge.

Ritesh Patil and M.Jamnu 2014) are researching the different mechanical properties of concrete that contains hypo sludge. Hypo sludge had been used as a replacement for cement. The percentages of substitution used during the present study were $10 \%$, $15 \%, 20 \%, 25 \%$.On 3days, 7 days and 28days, compressive strength of cubes was found. The specimens' 28th day flexural resistance and split tensile strength were found on the beams and cylinders respectively. Replacement of the hypo sludge is found to have beneficial effects on the concrete's mechanical properties.

Jayeshkumar pitrodaet al (2013) thistest should measure the absorption rate of water through capillary suction, unsaturated concrete's sorptiveness. In this paper, there is an attempt to study the properties of concrete from the Paper Industry Waste (Hypo Sludge) to check durability. The mix design for concrete grade M25 and M40 was conducted according to IS code.

$\mathrm{R}$ Srinivasan et al (2010) this research is an experimental study of concrete strength and optimum percentage of partial replacement by

Table.1 Chemical properties of fly ash, hypo sludge and ordinary portland cement (OPC)

Replacing cement with $10 \%, 20 \%, 30 \%, 40 \%, 50 \%$, $60 \%$ and $70 \%$ of Hypo Sludge.
Replacing the maximum amount of cement in concrete with a hypo sludge

To study fly ash hypo sludge concrete behaviour.

To study concrete's strength behaviour if partially replaced with hypo sludge.

To improve concrete's compressive strength.

To know what percentage of hypo sludge we'll reach full concrete strength.

To provide most cost-effective concrete.

\section{Experimental work}

\subsection{Process}

\subsubsection{Materials:}

Hypo sludge:Hypo sludge is gathered in the paper industry. The paper industry produces various forms of waste from which hypo sludge, known as preliminary waste, is used. Hypo sludge is acting like cement because of the silica and magnesium properties.

Fly ash: Class F fly ash is used.

Cement: Ordinary Portland cement 53 grade is used.

Fine aggregate: Around $4.75 \mathrm{~mm}$ to 150 microns, such fractions are considered fine aggregates. The river sand used as a fine aggregate conforming to IS: 383

Coarse aggregate: The $20 \mathrm{~mm}$ to $4.75 \mathrm{~mm}$ fractions are used as coarse aggregates conforming to IS: 383

Water: Portable water is used, $\mathrm{pH}$ value is should not be less than 6 .

Table 1: Chemical properties of fly ash, hypo sludge and ordinary portland cement (OPC)

\begin{tabular}{|c|c|c|c|}
\hline $\begin{array}{l}\text { Chemical } \\
\text { Properties }\end{array}$ & $\begin{array}{l}\text { Fly ash } \\
\text { (Percent } \\
\text { by mass ) }\end{array}$ & $\begin{array}{l}\text { Hypo } \\
\text { sludge } \\
\text { (Percent } \\
\text { by mass) }\end{array}$ & $\begin{array}{l}\text { Ordinary } \\
\text { Portland } \\
\text { Cement } \\
\text { (OPC) } \\
\text { (Percent } \\
\text { by mass) }\end{array}$ \\
\hline $\begin{array}{l}\text { Silicon } \\
\text { Dioxide } \\
\left(\mathrm{SiO}_{2}\right)\end{array}$ & 62.22 & 5.28 & 21.77 \\
\hline $\begin{array}{l}\text { Magnesium } \\
\text { Oxide }(\mathrm{MgO})\end{array}$ & 6.09 & 6.41 & 2.71 \\
\hline $\begin{array}{l}\text { Calcium } \\
\text { Oxide }(\mathrm{CaO})\end{array}$ & 5.30 & 47.84 & 57.02 \\
\hline $\begin{array}{l}\text { Aluminium } \\
\text { Oxide }\left(\mathrm{Al}_{2} \mathrm{O}_{3}\right)\end{array}$ & 7.63 & 0.09 & 2.59 \\
\hline $\begin{array}{l}\text { Sulphur } \\
\text { Trioxide } \\
\left(\mathrm{SO}_{3}\right)\end{array}$ & 3.0 & 0.19 & 2.41 \\
\hline $\begin{array}{l}\text { Ferric Oxide } \\
\left(\mathrm{Fe}_{2} \mathrm{O}_{3}\right)\end{array}$ & 0.13 & 0.73 & 0.65 \\
\hline
\end{tabular}

\section{Objectives}




\subsubsection{Mix proportion:}

Table 2 Mix proportions for M20 grade concrete as per IS 10262-2009. to MIX3 the percentage of increase in compressive strength is 22.83 percent. From MIX1 to MIX4 the percentage of increase in compressive strength is 28.05 percent. From MIX1 to MIX5 the percentage

\begin{tabular}{|c|c|c|c|c|c|c|c|c|}
\hline $\begin{array}{c}\text { Sample } \\
\text { number }\end{array}$ & $\begin{array}{c}\text { cemen } \\
\mathrm{t} \\
\text { replac } \\
\text { ed by } \\
\text { hypo } \\
\text { sludge }\end{array}$ & $\begin{array}{c}\text { cement } \\
\text { replaced } \\
\text { by fly } \\
\text { ash }\end{array}$ & $\begin{array}{c}\text { Cement } \\
(\mathrm{Kg} / \mathrm{m} 3\end{array}$ & $\begin{array}{c}\text { Hypo } \\
\text { sludge } \\
(\mathrm{kg} / \mathrm{m} 3)\end{array}$ & $\begin{array}{c}\text { Fly ash } \\
(\mathrm{kg} / \mathrm{m} 3)\end{array}$ & $\begin{array}{c}\text { Fine } \\
\text { aggregate } \\
(\mathrm{kg} / \mathrm{m} 3)\end{array}$ & $\begin{array}{c}\text { Coarse } \\
\text { aggregate } \\
(\mathrm{kg} / \mathrm{m} 3)\end{array}$ & W/c ratio \\
\hline 1 & 0 & 0 & 259.754 & 0 & 0 & 288.612 & 456.970 & 0.4 \\
\hline 2 & 3 & 5 & 238.975 & 7.792 & 12.987 & 288.612 & 456.970 & 0.4 \\
\hline 3 & 6 & 5 & 231.182 & 15.585 & 12.987 & 288.612 & 456.970 & 0.4 \\
\hline 4 & 9 & 5 & 223.39 & 23.377 & 12.987 & 288.612 & 456.970 & 0.4 \\
\hline 5 & 12 & 5 & 215.597 & 31.170 & 12.987 & 288.612 & 456.970 & 0.4 \\
\hline 6 & 15 & 5 & 207.804 & 38.963 & 12.987 & 288.612 & 456.970 & 0.4 \\
\hline
\end{tabular}

\section{METHODOLOGY:}

In this experiment cement is partially replaced by hypo sludge and fly ash with the percentages are above mentioned in table2. Batching was adopted weighing of each concrete constituent by a determined sum based on the mixing ratio of $1: 1.11: 1.76$. The constituents were then thoroughly mixed before reaching a consistent blend. Water was then added, and the mixture was repeated. The fresh concrete mix was then put in a mould of $150 \mathrm{~mm}$ size, compacted, and left for 24 hours before curing, the curing was done for 28 days, and the strength tests are conducted at 3 days, 7 days and 28 days

$150 \mathrm{~mm} * 150 \mathrm{~mm} * 150 \mathrm{~mm}$ concrete cubes and $150 \mathrm{~mm}$ diameter, $300 \mathrm{~mm}$ height of cylinders are cast by using M20 grade concrete. Specimens with ordinary Portland cement (OPC) and OPC replaced with hypo sludge and fly ash percentages of $0 \%, 3 \%$, $6 \% 9 \%, 12 \%$ and $15 \%$ cubes, cylinders are casted. During casting the specimens are mechanically vibrated vibrator. After $24 \mathrm{hr}$ the specimens is remove from the mould and subjected to water curing for 28 days. After curing, the specimens are tested for compressive strength using a calibrated compression testing machine of 2,000 KN capacity. See Table 3 for strength results.

\section{Results and Discussion}

From Table 3 it is observed that compressive strength and split tensile strength increases up to certain percentages of replacement of cement with Hypo sludge and Fly ash, and decrease further if we go on replacing cement with Hypo sludge and Fly ash. From MIX1 to MIX2 the percentage of increase in compressive strength is 7.37 percent. From MIX1 of increase in compressive strength is 20.84 percent. From MIX1 to MIX6 the percentage of increase in compressive strength is 10.07 percent. Here we can observe that the compressive strength goes on decreasing from MIX4 to MIX5 and MIX5 to MIX6.

In the case of split tensile strength the performance is as given here. From MIX1 to MIX2 the percentage of increase in split tensile strength is 8.57 percent. From MIX1 to MIX3 the percentage of increase in split tensile strength is 17.14 percent. From MIX1 to MIX4 the percentage of increase in split tensile strength is 25.14 percent. From MIX1 to MIX5 the percentage of decrease in split tensile strength is 4.57 percent. From MIX1 to MIX6 the percentage of decrease in split tensile strength is 11.47 percent. It is noticed that the split tensile strength goes on decreasing from MIX4 to MIX5 and MIX5 to MIX6. Also it is noticed that the split tensile strength decreases from MIX1to MIX5 and MIX1 to MIX6. Based on this it is clear that MIX4 is best i.e 9percent Hypo sludge and 5 percent Fly ash.

\section{Conclusion}

1. As the percentage of hypo sludge replacement increases, the compressive strength decreases.

2. Optimum level of replacement is $9 \%$

3. Since the expense of hypo sludge is less, this mortar may be used at the position where strength is not of greater importance or where stability is of temporary importance. 
Table 3: Compressive strength and Split tensile strength.

\begin{tabular}{|c|c|c|c|c|c|c|c|}
\hline \multirow{2}{*}{ s.no } & \multirow{2}{*}{ Mix } & \multicolumn{3}{|c|}{ Compressive strength (Mpa) } & \multicolumn{3}{c|}{ Split tensile strength (Mpa) } \\
\cline { 3 - 8 } & & 3 days & 7 days & 28 days & 3 days & 7 days & 28 days \\
\hline 1 & MIX1-S0 & 19.43 & 21.06 & 24.28 & 1.26 & 1.43 & 1.75 \\
\hline 2 & MIX2-S3 & 20.01 & 22.91 & 26.07 & 1.32 & 1.49 & 1.90 \\
\hline 3 & MIX3-S6 & 23.76 & 27.03 & 29.82 & 1.39 & 1.52 & 2.05 \\
\hline 4 & MIX4-S9 & 26.83 & 29.69 & 31.09 & 1.46 & 1.67 & 2.19 \\
\hline 5 & MIX5-S12 & 25.92 & 28.65 & 29.34 & 1.38 & 1.55 & 1.67 \\
\hline 6 & MIX6-S15 & 22.79 & 24.93 & 26.19 & 1.30 & 1.48 & 1.55 \\
\hline
\end{tabular}

\section{References}

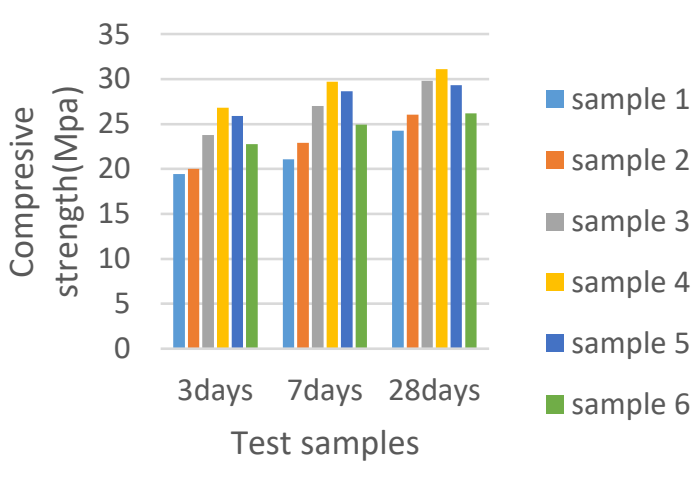

Fig1: compressive strength

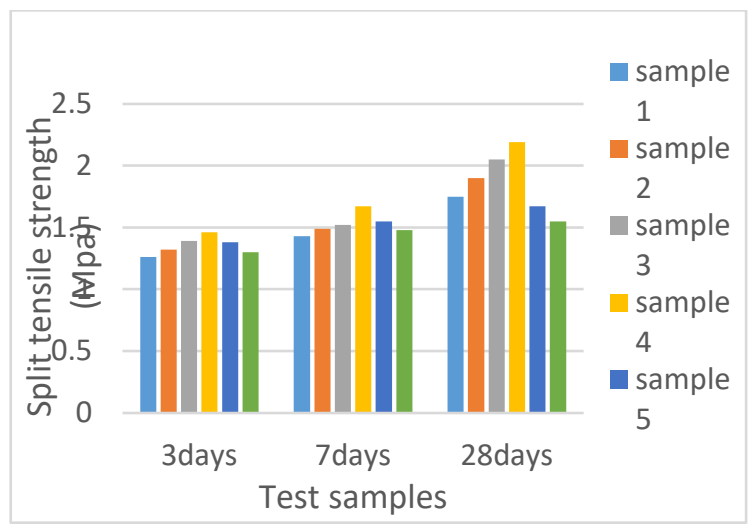

Fig 2: split tensile strength

4. The low cost concrete will minimize the environmental impact from waste and the residual amount of cement production.

5. This project will mitigate the disposal issue of the hypo sludge, nowadays it is a major challenge to obtain the landfill

6. This material can be used for economic feasibility as government implements the projects for temporary shelters for who those affected by natural disasters.
1. R. Srinivasan, *k. Sathiya and m. Palanisamy "experimental investigation in developing low cost concrete from paper industry waste" (2010)

2. Y.d. shermale, m.b .varma "effective use of paper sludge (hypo sludge) in concrete" journal of ijsrd,vol.3,issue 08,issn (online):2321-0613, (2015)

3. P.packialakshmi, r.aasha jyothi "experimental investigation on concrete using hypo sludge and wood ash" journal of ijar, volume 4 , issue 4 , 1243-1250 (2016)

4. Digpal singh raghuwanshi, rajesh joshi, "experimental study on paper sludge as cement replacement in cement concrete" journal of ijsrd vol. 5, issue 10, 2017

5. Dr.ram kishore manchiryal, kiran kumar poloju, chiranjeevi rahul $r$ " advancement in physical properties of hypo sludge concrete" international journal of scientific \& engineering research, volume 7, issue 9 , september-2016

6. Dr. Jayeshkumar pitroda "gainful utilization of fly ash and hypo sludge in concrete" (ijcrce) volume 1, issue 1, june 2015, pp 1-7 www.arcjournals.org

7. Santosh ahirwar, dr. Rajeev chandak "effective use of paper sludge (hypo sludge) in concrete" journal of ijedr 2018 | volume 6 , issue 2

8. Er. Siddharth talsania, dr. Jayeshkumar pitroda "innovative use of paper in waste (hypo sludge) in pervious concrete" international journal of constructive research in civil engineering (ijcrce) volume 2, issue 3, 2016, pp 24-32 issn 2454-8693 (online)

9. Vinay pingle, sanajay saraswat "experimental study of use of brine sludge in cement concrete"journal of ijsrd vol. 6, issue 09, 2018

10. Y. Suneel kumar, k.j. brahma chari, dr. N. Srujana "effect of strength parameters in concrete with partial replacement of cement using hypo sludge by adding fibers" international journal of civil engineering and technology (ijciet) volume 8 , issue 4 , april 2017, pp. 456-46 